Christine Chojnacki*

\title{
Charming bouquet or wedding garland? The structures of the Jain heroine 'novel' in Prakrit From Kuvalayamālā (779) to Manoramā (1082)
}

DOI 10.1515/asia-2015-0063

Abstract: It is undisputed that Bāṇa's Kādambarī has marked a turning point in the history of Indian literature not only because it introduced an elegant prose form into the kāvya style, but also because it evinced a unitary and complex plot that was a complete innovation as compared to the juxtaposed structure of contemporary works like Daṇdin's Daśakumāracarita. As a much admired work, Kādambarī is known to have influenced many poets and playwrights in the following centuries throughout India. However, it is often ignored that with its romantic themes and narrative structures Bāna's work has also inspired several Jain 'novels' named after a heroine in various forms and languages from the eighth to the eleventh century. The aim of the following paper is to concentrate on the Jain heroine 'novels' in Prakrit and to examine which aesthetic or religious reasons motivated the Jain monk-poets, to begin with Uddyotana, to deviate from the usual structure of a long Jain narrative, such as Haribhadra's Samarāiccakahā, and to adopt for their heroine 'novels' in Prakrit a difficult and totally new model of narration.

Keywords: Indian novel, Jain narrative, Kādambarī, heroine, Prakrit literature

The choice of the designation 'novel' adopted in this paper for the genre of a long narrative named after a heroine is deliberate, but it is not straightforward. ${ }^{1}$ Indeed, as it has been often underlined in literary criticism, the narrative genre has not been codified in the same way as poetry or drama and had very disparate embodiments in content (marvellous, realistic), as well as in

1 This paper is a much revised version of a talk I gave during the Deutscher Orientalistentag organised in Münster in September 2013.

*Corresponding author: Christine Chojnacki, Professor and Director of the Department of Indology, Université Lyon 3, 6 cours Albert Thomas, Lyon 69008, France.

E-mail: christine.chojnacki@univ-lyon3.fr 
form (prose or verse), which has led to various designations. ${ }^{2}$ Moreover, the term 'novel' in English does not have the same connotations as the corresponding word 'roman' in French. As a matter of fact, the French term was created according to the popular language in use, Roman instead of Latin, and had its roots in medieval narratives in verse; ${ }^{3}$ as for the English word, it was adopted as the expression of the change in the society of the eighteenthnineteenth centuries and its reflection in the content of "a long prose narrative whose well-constructed plot stays close to everyday life and whose characters have both virtues and faults". ${ }^{4}$

A first consequence of this complex situation has been that, in order to take into account the difference between the French and the English, modern critics have felt the need to add an adjective to the French and to speak of a modern form in prose "roman moderne" in opposition to an ancient form insisting on the marvellous content and corresponding to the English "romance". 5 A second consequence has been the dual attitude towards the label 'novel'. Indeed, on the one hand, in spite of the great liberty of the genre, there has been the tendency, not unaffected by ideology, to refuse to designate as 'novel' any narrative of world literature that was not in prose and that was prior to the seventeenth century, a period that saw the rise of the Spanish and the French novels composed, respectively, by Miguel de Cervantes and Mme de Lafayette, or to the eighteenth century with the apparition of the English novel as created by Daniel Defoe or Samuel Richardson. ${ }^{6}$ As a result, scholars of classics had to argue for extending the term 'novel' to ancient Greek and Latin prose narratives. As recalled by A. Billault, this was done for instance by the seventeenth century scholar Pierre-Daniel Huet in his Lettre sur l'origine des romans, but it remains

2 While some rather dwell on the type of discourse (narrative, story), others utilise distinctions depending on the length (short story, novel) or the content (tale, romance, novel); and in some other cases, adjectives are added in order to specify the form (poetic novel), the content (heroic novel), or the aim (didactic novel). Cf. Raimond 2015: 28-30; Valette 2005: 6-8; Chartier 1996: 1-6. 3 Cf. Raimond 2015: 27; Rey 1997: 6; Pavel 2013: 17.

4 Cf. Pavel 2013: 6, and particularly, 1: "There is a widespread view that the novel emerged relatively late in history, as a literary expression of modernity. Just as the Enlightenment swept away obsolete kinds of narratives - sometimes called romances - looked at life through distorting lenses, and portraying idealized, implausible characters, the novel, we are told, turned its attention to the ordinary lives of real people in the real world."

5 Cf. for instance Raimond 2015: 30 (quoting the classification made by Larousse in the nineteenth century); Rey 1997: 3-4. On the differences between a romance and a novel in English, cf. Pavel 2013:17.

6 Cf. Pavel 2013: 1. 
disputed whether Greek narratives can be considered 'novels'. ${ }^{7}$ Similarly, if there have been attempts since the last century to designate as 'novels' classical Indian narratives, ${ }^{8}$ the idea is still well-established in contemporary writings that the 'Indian novel' started with the first English novels written in India.' Thus, while the differentiation in labels between 'romance' and 'novel' shows an awareness of the remarkable innovations introduced into the narratives of the eighteen-nineteenth centuries, it also tends to occlude the fact that the modern forms of narratives called 'novels' could come into existence only through continuous literary innovations in world literature, as Samuel Richardson had realised. $^{10}$

In contradistinction, there has also been the temptation to designate as 'novel' every form of narrative. Thus, in 1862, A. Chassang placed under the term 'novel' every Greek text relating invented facts of a marvellous nature. ${ }^{11}$ Much more recently, S. Moore stated in his book The Novel: An Alternative History: Beginnings to sixteenth Century: "In my ecumenical view - schooled by the wild variety of forms, the novel has taken in the last century - any book-length fictional narrative

7 Cf. Billault 1991:10-11, referring to the work of Pierre-Daniel Huet, who wrote to Segrais his Lettre sur l'origine des romans in order to rehabilitate the ancient novels in their roles and rights and defined them as "histoires feintes d'aventures amoureuses écrites en prose avec art pour le plaisir et l'instruction des lecteurs" distinct from the other forms of fiction.

8 Thus while Glasenapp 1929: 182 stated that the Indian long narratives were not 'novels' like the Bengali works of the nineteenth century because of their fabulous content, he further said that they should nevertheless be counted as 'novels' since their plot was not deprived of suspense ("Es sind dieses keine Romane im Sinne der modernen bengalischen Prosaisten, die wie Bankimcandra Catțopādhyāya, Tāraknāth Ganguli, Rabindranāth Ṭākur ein realistisches Bild indischen Lebens geben, sondern durchaus Märchenbücher, bei denen das Überirdische eine grosse Rolle spielt [...] Trotz dieser preziösen Form des Ausdrucks und des durch sie bedingten langsamen Fortschreitens des Handlung sind diese Werke darum doch nicht ohne Spannung und dürfen mit Recht als Romane gelten"). On the contemporary hesitation between 'romance' and 'novel', cf. n. 5.

9 Mukherjee 2008: 106 states that "Literary historians have cited different dates for the first Indian novel, with Bengali and Marathi vying for first price, but it is by and large agreed that the novel came into existence in India in the second half of the nineteenth century. This was roughly a generation after Macaulay's 'Minute' decreed English as the language of higher education, exposing an entire class of urban Indian men to British narrative models. But before the new paradigms got indigenised, pre-novel forms of fiction existed in most Indian languages".

10 Cf. Pavel 2013: 5, "While the early period should not be seen as mere preparation for a genuine rise of the novel in the eighteenth century, its achievements did play a major role in the subsequent history of the genre. Samuel Richardson, a self-taught writer, realized that the best features of the older narrative subgenres could be mixed together".

11 Cf. Billault 1991:12. 
can be called a novel". ${ }^{12}$ And further, "a 'novel' is a prose composition longer than a short story, either fictitious in content or in its treatment of historical events, 'worked out with an eye toward a strategy of effects"'. ${ }^{13}$ Indeed the presentation of tales, short stories or romances as 'novels' reveals a desire to rehabilitate ancient forms of artistic narrative, as was the case with the ancient Greek novel, ${ }^{14}$ and to show how the various narrative forms and their continuous inventiveness have contributed to the novel of today. However, it is unfortunate that this attitude tends to serve the contrary purpose. In effect, how can one prove the boldness and innovation of an ancient narrative (such as the much admired Kādambari of Bāna), if one uses a single term that favours the confusion between a work with a complex plot and simple tales or collections of stories? ${ }^{15}$ Besides, in the case of Indian literature, such a position does not do justice to the variety of literary forms which the theoreticians had already recognised and distinguished. ${ }^{16}$ Thus the generalisation of the term 'novel' rather results in opposing again all the ancient narratives to modern 'novels' and in ignoring, at least on the surface, the modernity of many a brilliant work from the classical or medieval period. That is probably why S. Moore resorts to other ways to distinguish the Indian fictitious narratives he presents, such as degrees in the appreciation or differentiations in the structure. ${ }^{17}$

Therefore, instead of insisting on an opposition of 'romance' against 'novel' that cannot be satisfactorily answered, since part of the definition is based on the content, ${ }^{18}$ it seems appropriate in order to see the originality of Indian narratives

12 Cf. Moore 2010: 5.

13 “The quoted phrase is from Italo Calvino's Uses of Literature (p.109) and encompasses form, technique, style, tone, rhythm, intention, and other aspects of the novel. (Content does not matter: a novel can be about anything.)": cf. Moore 2010: 5. See also the definitions given for the novel by Littré "une histoire feinte, écrite en prose, où l'auteur cherche à exciter l'intérêt par la peinture des passions, des mœurs, ou par la singularité des aventures" or by the Robert "une œuvre d'imagination en prose, assez longue, qui présente et fait vivre dans un milieu des personnages donnés comme réels, nous fait connaître leur psychologie, leurs destins, leurs aventures" (Raimond 2015: 30).

14 See Pavel 2013: 17; Billault 1991.

15 For instance: Pañcatantra (Moore 2010: 409-411); Daṇin's Daśakumāracarita (Moore 2010: 434-437); Prabandhacintāmaṇi (Moore 2010: 438-439); Vikramāditya’s Simhāsanadvātriṃsikā (Moore 2010: 444-445).

16 Cf. infra, n. 19.

17 Thus, "the great Bāna, author of the two finest novels of this period" (Moore 2010: 427); Kādambari is an 'ambitious novel' whose writer "chose to challenge himself and his readers with an achronological narrative in an embedded structure five levels deep" (Moore 2010: 430); "Dandin wrote the most readerly of these learned, writerly novels" (Moore 2010: 434).

18 Not only is the 'novel' multi-faceted, but also its content is variously defined. For example, if one reason to exclude a work from the genre is marvellous content (Rey 1997: 6), there have been also many debates on the meaning of 'realism' (Rey 1997: 7): cf. Piegay-Gros 2005: 30-39. And it is an 
of the past to combine formal and structural criteria deriving from modern literary criticism (tale, short story, mini-novel, romance, novel) and classical Indian categories (kathā, ākhyāyikā, kāvya, gadya and padya) - also not without ambiguities $^{19}$ - as scholars such as H. von Glasenapp, L. Renou and S. Lienhard have done since the last century. Thus, they make a distinction within the Indian narratives between 'tales' with a simple structure and archetypal characters (such as the Pañcatantra), and 'novels'. ${ }^{20}$ If the first category was easy to define, since there were clear-cut formal criteria according to both Indian and Western theoreticians, the second one on inspection turned out to be composite. As a matter of fact, in respect to Indian theoreticians, the second group of Indian narratives belonged to the genre of kāvya that could be padya 'in verse' or more often gadya 'in prose' and that was characterised by exigent formal criteria. ${ }^{21}$ But this kāvya narrative could only partially fit the category of the 'novel' or 'romance' as defined by Western critics. ${ }^{22}$ This is visible through both the inconsistencies in respect to designations employed ${ }^{23}$ and the subdivisions they proposed for the genre of the kāvya narrative between extended tales with a simple and juxtaposed

irony of fate that D. Defoe who did not want his work to be labelled as a novel ended up by representing one of the first specimens of the genre in English literature (Raimond 2015: 28).

19 Kāvya 'poem' and kathā 'story' in particular can be genres, but they can also respectively designate 'ornate' and 'simple' styles; besides, other categories evolved: while ākhyāyikā was at first an 'experienced' story as opposed to kathā, a 'fictive' story, the two terms merged and the distinction was no longer valid (Lienhard 1984: 228-231).

20 Thus Glasenapp and Renou divide the narrative literature as follows: Glasenapp 1929, “Fabel und Märchenwerke” (pp.178-182) and "Kunstromane (pp.182-183); Renou 1985.2, “contes' (§ 1808-1834) 'roman' (§ 1835-1844); The same division does not occur in the book of Lienhard, since he deals with A History of Classical Poetry, but he also uses both Western and Indian categories: cf. n. 23.

21 See Glasenapp 1929: 182; Renou 1985, § 1835.

22 Cf. Glasenapp 1929: 182; cf. also Renou 1985, § 1835: “le petit groupe des romans n’est pas sans analogie avec la masse des contes; le sujet en effet est emprunté à la literature narrative, les procédés de composition (récit-cadre, etc.) sont similaires. Mais le roman est avant tout et foncièrement un $k \bar{a} v y a$, c'est-à-dire une œuvre d'art soumise aux mêmes conventions de forme et de fond que la haute lyrique ou l'épopée savante".

23 On the one hand, L. Renou 1985 adds adjectives more precisely to define the works he places under the label 'roman' : 'roman picaresque’ for Daṇdin’s Daśakumāracarita (§ 1836), 'sorte de roman historique’ for Bāṇa’s Harṣacarita (§ 1839), 'roman fantastique’ for Bāṇa’s Kādambarī (§ 1842) (cf. also Glasenapp 1929: 182-183, 'Kunstromane’); on the other hand, he expresses the difficulty in placing the Indian $k \bar{a} v y a$ narratives under a unique label by using dual expressions, such as 'conte amplifié' for Subandhu's Vāsavadattā (§ 1837) and 'roman-conte' for Kādambarī (§ 1838). In a similar way, S. Lienhard speaks of Bāṇa’s Kādambarī sometimes as a mahākārya in prose (1984: 138) or 'prose poem' (1984: 252), sometimes as a 'novel' (1984: 151, 244). 
structure, such as Daṇ̣in's Daśakumāracarita, ${ }^{24}$ and composed 'novels' with a complex central plot (all episodes of which are necessary) and developed characters (who evolve in the narrative), such as Bāna's Kādambarī. ${ }^{25}$ Thus, with the clear-cut criterion of the structures, scholars established, within the kāvya narrative literature, a gradation from the loosest up to the most complex and intricate structure and unanimously singled out Bāṇa's Kādambarī as a prose masterpiece. $^{26}$

Indeed, if it is still debated whether Kädambari is a romance or a novel, ${ }^{27}$ it is undisputed that it has marked a turning point in the history of narrative literature, not only through its poetic achievements or its new conceptions, ${ }^{28}$ but also through its achronological and embedded structure that becomes even more complex because of the various and uneven incarnations of its main characters. $^{29}$ Thus, firstly, while the heroines Mahāśvetā and Kādambarī, both the daughters of celestial beings (a Gandharva and an Apsaras), remain the same throughout the narrative, the male characters have several incarnations during which their souls not only transmigrate from one body to another but can also revert to a previous existence (Table 1).

24 Renou 1985, § 1836: "Le Daśakumāracarita est de tous les romans le plus voisin des contes dont il emprunte la presentation à tiroirs et le riche matériel folklorique".

25 Cf. Renou 1985, § 1841: "l'affabulation est particulièrement complexe"; see also Lienhard 1984: 252; Shulman 2014: 277.

26 Kādambarī is presented as a Sanskrit prose masterpiece (Pollock 2006: 434), as "arguably the finest extant exemplar of sustained Sanskrit prose" (Shulman 2014: 277); as "der Höhepunkt der kunstvollen Prosa" (Glasenapp 1929: 182), as "a great novel” (Lienhard 1984: 151), as "un spécimen achevé de kathā en prose” (Renou 1985: §1844). As compared to Dandin's Daśakumāracarita, Bāṇa's Kādambari "reflects an extended moment of creative experimentation, not only with the possibilities of prose of as a style but also with the system of genres". cf. Innovations and Turning Points 2014: 233.

27 It is called a 'novel' by Glasenapp 1929: 182, Renou 1985: § 1838, Lienhard 1984: 194, 200, Warder 1994, vol. IV: § 1696), a 'romance' by Winternitz 1991: 463, Tieken 2014: 89, Shulman 2014: 277; a 'prose poem' by Tubb 2014a: 314.

28 Cf. Glasenapp 1929: 183, "Wie Jasmingirlanden, denen kunstvoll Goldblumen eingewoben sind - um ein von Bāṇa selbst gebrauchtes Bild zu verwenden - sind seine Wortgebilde mit äusserstem Geschick in ihrer verwirrenden Fülle aneinandergewunden, wie an einem schimmernden Geschmeide leuchten hier die mit raffiniertem Geschmack ausgewählten Wortedelsteine in vielseitigem Glanz von Sinn und Doppelsinn und zaubern dem Leser, der sich in sie vertieft, jeden Augenblick kaleidoskopartig neue Bilder vor, die andern neuen Erscheinungen in schnellstem Tempo Platz machen”. Tubb 2014a: 308-356 defines four types of boldness in his article: A. striking verbal technique (1. Expressive repetition of sounds; 2 . Expressive choices in the length of compounds); B. Conceptual courage (1. Daring choices in subject matter; 2. Daringly novel or complex conceptions).

29 Cf. Moore 2010: 430-432; see also Shulman 2014: 277-307. 
Table 1: Incarnations in Kādambarī.

\begin{tabular}{|c|c|c|c|}
\hline Life 1 & Life 2 & Life 3 & Life 4 \\
\hline $\begin{array}{l}\text { Puṇụarīka } \\
\text { ascetic } \\
\text { Mahās̄vetā } \\
\text { Apsaras }\end{array}$ & $\begin{array}{l}\text { Vaiśampāyana } \\
\text { Minister }\end{array}$ & Parrot & $\begin{array}{l}\text { Puṇdarīka } \\
\text { ascetic }\end{array}$ \\
\hline $\begin{array}{l}\text { Kapiñjala } \\
\text { ascetic }\end{array}$ & $\begin{array}{l}\text { Indrāyudha } \\
\text { horse }\end{array}$ & & $\begin{array}{l}\text { Kapiñjala } \\
\text { ascetic }\end{array}$ \\
\hline moon & $\begin{array}{l}\text { Candrapīḍa } \\
\text { prince }\end{array}$ & $\begin{array}{l}\text { Śūdraka } \\
\text { King }\end{array}$ & $\begin{array}{l}\text { Candrapīda } \\
\text { prince }\end{array}$ \\
\hline $\begin{array}{l}\text { Kādambarī } \\
\text { Apsaras }\end{array}$ & & & \\
\hline
\end{tabular}

Secondly, the author does not start with the beginning of the story to reach the end but he begins in the middle of the story, continues with flashbacks, and then after a cascade of narrations finishes his novel with a parrot telling a king named Sūdraka a story that eventually appears to be the story of their own adventures in previous lives.

Thirdly, contrary to the tales of the Pañcatantra, for example, the embedded stories are not independent tales but are related to the main story with the same heroes, and all the four levels of stories integrated in the first level of narration are perfectly linked to each other (they are named respectively A to E: Table 2).

Table 2: A structural analysis of Kādambarī.

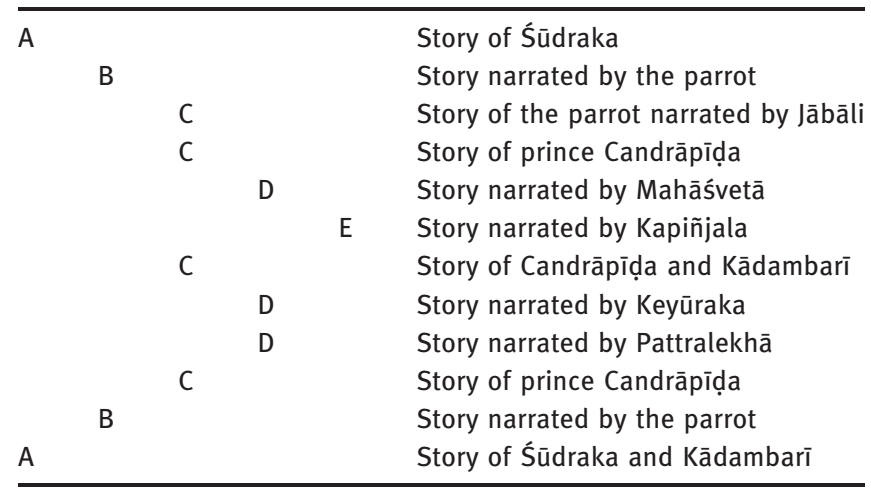

Therefore, I have chosen the convenient term 'novel' notwithstanding all its ambiguities for this narrative named after its heroine, since it can highlight the modernity of its narrative structures, the remarkable innovations it involved and the new paths it opened to successors in Indian narrative literature. 
Indeed, as stated by S. Lienhard in his book A History of Classical Poetry (1984) and by Yigal Bronner, David Shulman, and Gary Tubb in their book Innovations and Turning Points: Toward a History of Kāvya Literature (2014), Kādambar̄ was much admired soon after its composition and had a considerable influence on the following generations of poets and readers as well. ${ }^{30}$ For instance, a passage from the Kharataragacchabrhadgurvāvali shows how Bāna's work, a kathā in the gadya$k \bar{a} v y a$, was considered to be the best representative of the poetic narrative genre; ${ }^{31}$ and later on, as noted by Filliozat and Shulman, its title in Kannara and in Marathi became the generic term for 'romance'/"novel'. ${ }^{32}$ Kãdambari was summarized and adapted, ${ }^{33}$ inspiring many an author to create original works in various forms. If some of them were written in prose like their model, paradoxically (or maybe not so, if we consider the convincing argument of G. Tubb that Kādambari is rather 'a poem in prose' than a 'poetic novel ${ }^{34}$ ), most of them were composed in verse $\mathrm{e}^{35}$ or in a mixed form of prose and verse. ${ }^{36}$ Another oddity is that Bāna did not initiate among Hindu authors a literary movement of heroine 'novels' in prose, but rather inspired either plays (Bhavabhūti’s Mahāvīracarita, Rājaśekhara’s Bālarāmāyaṇa, Murāri's Anargharāghava) or versified poems in Sanskrit or in Prakrit (Vākpatirāja's

30 Cf. Innovations and Turning Points 2014: 355-490, V. The Sons of Bāna (Abhinanda; Bhavabhūti; Rājaśekhara; Murāri); Lienhard 1984: 257: "It is obvious that Bāṇa rapidly gained the reputation of being the greatest master of Sanskrit prose so far to appear. His work was regarded as unsurpassable and his name was soon mentioned together with Kālidāsa and other famous poets. To future generations of poets the Harșacarita and Kādambari were the models both for prose style and for prose novels". See also Glasenapp 1929: 183 "vom Standpunkt der indische Kunstdichter stellt das Werk eine unübertroffene literarische Glanzleistung dar"; Renou 1985: §1842: "Du point de vue indien, Kādambarī est une oeuvre reputée, citée avec admiration, maintes fois imitée et traduite".

31 For each genre, only one work is given (cf. KhG 39.33-40.1): haimavyākarana-prabhṛtīi lakṣaṇa-śāstrāṇi, māgha-kāryādi-mahākāvyāni, kādambaryādi-kathāh, murāri-mukhyāni nāțakāni, jayadevādi-chandāṃsi, kandali-kiraṇāvaly-abhayadeva-nyāya-pramukhās tarkāḥ, kāryaprakāśapramukhā alarikārāh, siddhāntāś ca sarve'pi.

32 Filliozat 1994: 24; Shulman 2014: 277.

33 From the ninth century summary called Kādambarikkathāsāra by Abhinanda (Lienhard 1984: 200; Renou 1985: § 1784) to Bhālan’s Gujarati adaptation of Kādambarī in the fifteenth century (Renou 1985: § 1844; Pollock, 2006: 434).

34 Cf. Tubb 2014a: 308-354.

35 Bāṇa is considered to stand among the best poets by Vidyākāra who quotes his verses in his anthology Subhāṣitaratnakośa: cf. Lienhard 1984: 87-88; it is also noteworthy that, despite being mainly an author of poetic prose, Bāna inspired many authors who chose to write in verse: see Tubb 2014a: 308-354.

36 If Kādambari was considered to be the best specimen of the kārya in prose, it "also introduced a new level of vigor, recognized by later poets as a kind of attractive boldness (prāgalbhya), even in his Sanskrit verse": Innovations and Turning Points 2014: 234. 
Gaudavaha, Abhinanda's Rāmacarita) dealing with topics different from fanciful love stories.

The first Indian writers to have taken up this model of heroine 'novels' over a period of about four centuries were Jain authors. Admittedly, the Jains had produced novels associated with heroines from an early date. Indeed, they often quoted among their own models Pādalipta's Tarangavai ${ }^{-37}$ whose text has not survived. Yet there seems to have existed a real fascination with Bāṇa's Kādambarì's attractive formal beauty, since no less than nine heroine 'novels' were produced from the eighth century to the twelfth century in Sanskrit or in Prakrit, in the form of a 'mini-novel' or in the longer form of a 'novel', in verse or in campū. They are as follows: ${ }^{38}$

- 779 Kuvalayamālā of Uddyotana (prakrit, 13000 granthas; campū form)

- ca. 800 Līlāvaī of Koūhala (prakrit, 1333 verses)

- 918 Bhuyaṇasuṃarī of Vijayasiṃha (prakrit, 8941 verses)

- ca. 970 Tilakamañjarī of Dhanapāla (sanskrit, ca. 4300 granthas, campū form)

- 1035 Nivvānalīlāvaī of Jineśvara (prakrit, 15000 granthas; campū form) ${ }^{39}$

- 1038 Surasuṃdarī of Dhaneśvara (prakrit, 4001 verses)

- Before 1050 Udayasuṃdarī of Soḍḍhala (sanskrit, ca. 4500 granthas?, campū form)

- 1083 Maṇoramā of Vardhamāna (15000 granthas; campū form)

- 1129 Nammayāsuṃarī of Mahendra (prakrit; 1117 verses) $)^{40}$

If the Jain heroine 'novels' in Sanskrit have found their way into various histories of Indian literature, their counterparts in Prakrit have been unevenly

37 There already existed before Kādambari a famous work in Prakrit named after a heroine: Tarangavai of Pādalipta whose date is debated (in the first centuries of the Christian Area: Filliozat 1994: 325; before the fifth century: Winternitz 1991: 522; see also Warder 1990, vol. II: $\S 835-850)$. Unfortunately, the work is now lost and known only through its adaptations, the earliest being "possibly of the tenth century", also in Prakrit (Bhayani 1979: preface).

38 After Bāna, there exists in Sanskrit a work named after a heroine composed by King Bhoja: Śrngāramañjarīkathā (composed before 1050). There also exists a short work in Apabhramía based on a feminine character dealt with in Haribhadra's Samarāiccakahā, Sādhāraṇa's Vilāsavaī dated 1066.

39 The work of Jineśvara is now lost, but its structure can be perceived through its epitome Lìlāvatisāra composed in 1284 by Jinaratna (ca. 5000 granthas; campü): cf. Fynes 2005 and 2006; see also Chojnacki 2016a and Chojnacki 2016b (forthcoming).

40 For most of the works in Prakrit, a date is given in the final praśasti. Lìlāvaī is not dated, but A.N. Upadhye attributes the work to ca. 800 (cf. Upadhye 1949: 69-75); as for Vijayasiṃha's Bhuyanasumdarī, the date is not mentioned at the end of the work, but in the Bṛhaținipanik $\bar{a}$, an old list of Jaina works dated 1383, as V.S. 975 (cf. Velankar 1944, s.v.). 
explored. ${ }^{41}$ The first two pioneering compositions - Lìlāvaì among the 'mininovels ${ }^{42}$ and Kuvalayamālā among the 'novels'- are the most well-known thanks to A.N. Upadhye's remarkable editions and comprehensive introductions. ${ }^{43}$ The fact that the former has an intricate structure has been highlighted by this scholar; ${ }^{44}$ as for the latter, continuing the pioneering work of A. N. Upadhye, I have tried to show in the study I have dedicated to the work of Uddyotana that his Kuvalayamālā was innovative in many ways and constituted a milestone in Prakrit literature, comparable to Bāṇa's works in Sanskrit literature. ${ }^{45}$ Contrary to this, the four Jain heroine 'novels' in Prakrit that succeeded remained largely ignored in literary histories except Caudharī’s Jain Sāhitya kā Bṛhad Itihās and Warder's History of Kārya Literature. ${ }^{46}$

As indicated in their prefaces, ${ }^{47}$ the Jain monks who composed heroine 'novels' in Prakrit continued to have the same edifying intentions as in their

41 For the works in Sanskrit, Dhanapāla’s Tilakamañjarī (Lienhard 1984: 262; Warder 1988, vol. V: § 4210-4289; Renou 1985: § 1844; Winternitz 1991: 534); Soḍḍhala’s Udayasundarī (Lienhard 1984: 263; Warder 1992, vol. VI: § 4585-4629; Renou 1985: § 1844; for the works in Prakrit: S. Lienhard mentions only Kuvalayamālā in his "History of Classical Poetry" (Lienhard 1984: 82, 266) and even A.K. Warder who takes many Prakrit works into account in his Indian Kāvya Literature (see infra n. 46) does not include Vijayasiṃha's Bhuyanasuṃdarī, since this work existed only in a manuscript form when he finished his volume $\mathrm{V}$ and became a book only in 2000 thanks to the work of the Jain monk Vijayaśilacandra.

42 This work, and also Mahendra's Nammayāsuṃdarī, will not be taken into account in this paper on the grounds of brevity and because the intention is not religious as in the other Jain Heroine 'novels' under investigation.

43 Cf. Upadhye 1949 (introduction: 1-87); Upadhye 1959 (for Kuvalayamālā’s text) and 1970 (introduction: 1-112).

44 Cf. Upadhye 1949: 45-46.

45 Cf. Upadhye 1970; Chojnacki 2008a, vol.1: particularly ch. 2: 43-74; ch. 4: 131-146. In the same way as Bāna, Uddyotana breaks on several occasions the narrative illusion, for instance, when he pretends to have forgotten to speak of the evil and the virtuous men and begins his narrative afterwards again.

46 Thus: Nivvāṇalīāâā (Caudharī 1973: 343-346; Warder 1992, vol. VI: §4668-4712); Surasuṃdarī (Caudharī 1973: 347-349; Warder 1992, vol. VI: §4715-4775); Maṇoramā (Caudharī 1973: 350; Warder 1992, vol. VI: §5424-5503); Bhuyaṇasuṃdarī (Caudharī 1973: 347). This can be explained by the fact that only Dhaneśvara's Surasuṃdari was edited long ago in 1916; the others were edited only relatively recently: Vardhamāna's Manoramā in 1983 and Vijayasiṃha's Bhuyaṇasuṃdarī in 2000; furthermore, apart from Jinaratna's Līlāvatīsāra, epitome of Jineśvara's lost Nivvānalīlāvaī (edited in 1983) that was translated in 2005 and 2006, the other works exist in limited editions that do not present an English introduction.

47 On the innovation of Bāna for Kādambari and on the Sanskrit literary texts with preface, cf. Innovations and Turning Points 2014: 88-93, 103. 
short stories. ${ }^{48}$ Indeed, they all indicated the religious purpose either by a specific category (dharmakathā) or by a qualifying expression. ${ }^{49}$ At the same time, however, as shown by the words kāvya or kathā to designate their works, ${ }^{50}$ they wanted to continue a movement initiated by Dharmasenagani ${ }^{51}$ and Haribhadra to attract a larger audience with the seductive content and beautiful form of long narratives written in kāvya style. ${ }^{52}$ But, while the forerunners composed their works with the usual linear structure of the collection of stories, the structural innovations introduced by Bāna tempted the authors of Jain heroine 'novels' to amplify formal beauty and to change the usual linear structure for the intricate plot of Kädambarì. Yet, did the Jain authors manage to introduce in their heroine 'novels' in Prakrit both the kāvya themes and the complex structures of Bāna's work? If so, why did they take a special interest in adapting Kādambarì's complex structures? And if these five heroine 'novels' shared similar features, was it because they were continuously attracted by Bāṇa's prose poem as the best form of narrative or because they constituted a literary school inspired by Kuvalayamālā, the pioneering work of Uddyotana?

It is certain that Uddyotana knew Bāna's Kãdambarī, since he locates it among the admired compositions of his illustrious predecessors in following terms:

48 Cf. Kuvalayamālā (1.19-7.3) - see also Chojnacki 2008a: 31-42; Bhuvaṇasuṃdarī (v. 6-31); Surasuṃdarī (1, v. 17-44); Maṇoramā (v. 13-56).

49 Thus Dhaneśvara (saṃvega-kariṃ kathām: v. 17); Vijayasiṃha (dhamma-uvaesa-ppayāṇa-suvisuddham kaham: v. 31); Vardhamāna says the religious purposes of each avasara of his work (v. 30-34).

50 Thus Uddyotana names his narrative: kahā (5.20), dharmakathā (5.11); Dhaneśvara kathām (v. 17; praśasti, v. 249) and kārya (v. 39); Vijayasiṃha sukaittaṇa (v. 12), kahā (v. 31); Vardhamāṇa kathā (v. 34; v. 1233).

51 Dharmasenagani's preface to his Vasudevahindimajjhimakhaṃda (1.14-2.8): "Since people keep hearing the stories dealing with the passionate loves of profane heroes such as Nahusa, Nala, Dumdhumāra, Nīkașa, Purūravas, Mandhāta, Rāma, Rāvaṇa, Yājnavālkya, the Kauravas, the Pāṇdavas, Naravāhanadatta and others, people have become interested only in love stories and they do not wish in the least to listen to dharma which leads to good destinies. They suffer from such indigestion from sugar and candy that a bitter taste comes in their mouth. Besides, though all kinds of happiness come from the dharma, people do not care for it. Therefore, I shall act as a doctor who is facing a patient turning his head away because he does not want to drink the medicine that would make him immortal, and I will give him this medicine mixed with his preferred drink. I shall pretend to give these intoxicated people a story with erotic feelings and actually teach them the dharma."

52 Thus, as regards the structure of the narrative, they introduced in the narration descriptions on expected themes and long reflexive dialogue, while as regards style they used several of the devices expected in an $k \bar{a} v y a$, for instance figures based on sounds, comparisons or long compounds. For a description in Uddyotana's see Chojnacki 2008a, Chapter 3: 101-123. 
She imparts the happiness of gracious words and shines with her gold and her jewels, she who was born of Bāna in the forest for Candrāpịda, Kādambarī. ${ }^{53}$

There is no doubt either that, behind the usual modesty, the Jain monk intended to present his Kuvalayamāla as a heroine who could be similarly attractive, albeit in another manner:

With its ornaments, its beauty, its lovely words, its sweet and enchanting discourse, (this narrative) gives joy to its friends, just like a newly-wed bride who is led by in her wedding procession.

Even if the present narrative cannot win over to itself your hearts, which have already been delighted by the narrative told by the excellent poets (of the past), it shall give (to you) nonetheless that same particular pleasure that is given by a young bride, as distinct from the pleasures that can be granted by an experienced and expert woman. ${ }^{54}$

The results do not fail to match authorial intention. ${ }^{55}$ Indeed, beside its new сатрй form, ${ }^{56}$ Kuvalayamāla $\bar{a}$ has a surprisingly modern structure that is far from the usual linear scheme of the collections of stories. Thus, while the Samaräiccakahā, an extensive narrative work written by his master Haribhadra in the eighth century, presents in succession nine stories in order to relate the adventures of two souls in the course of their existences, Kuvalayamālä's plot intertwines several levels of narration (A, B, C). ${ }^{57}$ In a first level of narration (A), Uddyotana narrates the adventures of Kuvalayacandra, son of the king of Ayodhyā, who is destined, according to a prophetic dream, to marry princess Kuvalayamālā after many perilous adventures. During his forced stay in an impenetrable forest, the prince happened to meet the monk Sāgaradatta who satisfied his curiosity by narrating a story. Here begins a second level of narration

53 Kuvalayamālā 3.26:

lāyaṇna-vayaṇa-suhayā suvaṇna-rayaṇ’ujjalā ya bāṇassa | caṃạ̄iṇ̃assa vaṇe jāyā kāyaṃbarī jassa \|

The author plays also with the double meaning of candrāpida, epithet of the god Śiva.

54 Kuvalayamālā 4.18-19:

sālaṃkārā suhayā laliya-payā mauya-maṃju-saṃlavā |

sahi-yāṇa dei harisaṃ uvvūạhā ṇava-vāhu ceva \|

su-kai-kahā-haya-hiyayāṇa tuṃha jai vi hu ṇa laggae esā |

poḍā-rayāo taha vi hu kuṇai visesam ṇava-vahu vva \|

55 On the prologue presenting Uddyotana's aesthetic aims, see Chojnacki 2008a, chap.1: 31-42; on Kuvalayamālā's structures, ibidem, chap. 2: 43-74.

56 For a discussion regarding the emergence of the campū genre before the tenth century, see Chojnacki 2015.

57 In the following outlines of the works, the narrative levels are indicated in italics and the analepses are presented in a table. 
(B) with the life of king Purandaradatta and his devoted minister Vāsava who under the pretext of admiring the beauty of the spring season in the royal park took the opportunity to bring the ruler to the monk Dharmanandana's preaching assembly. Then starts a third level of narration (C) with the successive stories of five souls who suffered each from the consequences of one of the five main passions, were enlightened by Dharmanandana and came to the agreement that the first one to acquire the right faith in his next existence would enlighten the four others. Here ends the level $C$. And, while the audience has gone deeper and deeper in the layers of the narrative, the narrator reassembles all the threads together. As a matter of fact, the monk Sāgaradatta further relates on the level $B$ that during the heavenly life that followed for the five souls, one of them reminded the others of the promise they made to each other during their human existence. It is he who came first as a human being again and led the life of a merchant who suffered many misadventures before becoming a monk. Here ends the level $B$ with the astonishing revelation made to the prince that the merchant in question was in fact Sāgaradatta himself, and that Kuvalayacandra was another of these five souls.

\begin{tabular}{|c|c|c|c|}
\hline \multirow[t]{11}{*}{ A } & & & Kuvalayacandra meets Sāgaradatta \\
\hline & B & & Story of king Purandaradatta, who meets Dharmanandana \\
\hline & & $\mathrm{C}$ & Story of Candasoma \\
\hline & & $\mathrm{C}$ & Story of Mānabhața \\
\hline & & $\mathrm{C}$ & Story of Māyāditya \\
\hline & & $\mathrm{C}$ & Story of Lobhadeva \\
\hline & & $\mathrm{C}$ & Story of Mohadatta \\
\hline & & C & Awakening of Purandaradatta \\
\hline & B & & Divine destinies of the five souls \\
\hline & & $\mathrm{C}$ & Story of the rat \\
\hline & B & & Story of Sāgaradatta, soul of Lobhadeva \\
\hline A & & & Story of Kuvalayacandra, soul of Mānabhața \\
\hline
\end{tabular}

At that point, the story reaches the level A again. The audience can follow the prince Kuvalayacandra in his adventures on his journey towards Vijayapurī town in which he eventually married princess Kuvalayamālā after various twists and turns, before returning to his father's kingdom in Ayodhyā.If the circle is complete for this life (actually the third existence of the five souls), the narrative does not stop there. Indeed, in a second part, the audience meets again the five souls in their last life before their liberation from the circle of existences. Consequently, if Uddyotana seems to be mainly interested in describing the chivalric and amorous adventures of prince Kuvalayacandra which he introduces in medias res, he actually presents his audience with the enlightening lives of five souls through their numerous existences. While doing so, he 
managed the feat of combining two narrative structures, on level C, the linear and juxtaposed structure of Haribhadra's Samaräiccakahā, and on the levels A and B the achronological and embedded structure of Bāna’s Kādambarī..$^{58}$

If Vijayasimha did not explicitly refer to Bāna among his predecessors and humorously said that while being seized by the demon of the poetic creation, he would perhaps arouse mockery,$^{59}$ he nevertheless opted for a similar complex plot for his Bhuvanasumdari in $\bar{a} r y \bar{a}$ verses. ${ }^{60}$ Thus, the Jain author begins his narrative with the life of prince Harivikrama on a first level of narration $(A)$. While he was sent by his father to discuss an alliance with neighbouring kings, this prince was taken away by a Vidyādhara and offered hospitality by a kulapati. On a second level of narration (B), this sage told him how he had come to live in the forest, beginning with the story of princess Candraśrī who had fallen in love with a prince but lost sight of him. Her friend Vilāsalakșmī asked a brahman nearby. The latter related the story of Prince Virasena on the level $C$ (between v. 1415 and v. 2099). Soon after his birth, this prince disappeared and was raised in the forest. One day, Virasena met the afore-mentioned kulapati and asked him to narrate his adventures. The kulapati agreed to the request and began his narrative. ${ }^{61} \mathrm{He}$ was a minister of Sürasena, the king of Campā and after being imprisoned several times, he decided first to become a kulapati and then a Jain monk. When the narration of Virrasena's past adventures ends, one reaches again level $C$. Then, after some time Candraśrī on level $B$ again met the prince she fell in love with but she was taken away by the Vidyādhara Aśoka. While searching for the villain, Vīrasena met two monks and adopted the vows of a layman. After many adventures, he eventually

58 Clearly following Uddyotana’s model, Jineśvara also gave his Nivvānalīlāvaī a complex structure to the extent that this can be assessed from his adaptation in Sanskrit by Jinaratna.The story begins like Uddyotana's novel in a courtly setting with the life of king Vijayasena in the level A. The scenario that follows, however, is more in keeping with the Jain box-stories and testifies to less originality. After some time, the prince met a Jain monk, Samarasena, who told him in the level $B$ why he had renounced the world. He himself became acquainted with another monk, Sudharman, who awakened him in the level $C$ by relating the stories of ten souls who had suffered from evil passions before adopting the Jain dharma. As in Uddyotana's work, this narration of the monk Samarasena in the level B expands over a great part of the work, since it occurs in Jinaratna's Lìlāvatīsāra from Chapter II, v. 1 to Chapter XVII, v. 4. On the principles of the summaries' faithfulness to the structure of the long narratives, see Chojnacki 2016a and Chojnacki 2016b (forthcoming).

59 Cf. Bhuvaṇasuṃdarī v. 12 : sa-cchaṃda-paya-payāro nirabhippāya-ppahāsaṇa-paro ya| su-kaittaṇa-gaha-gahio buhāna hāsaṃ gamissāmi || 12 ||

60 Vijayasiṃha seems to inscribe himself in the literary traditions of both Prakrit (Pādalipta, Bappahațịi, Haribhadra: v. 10) and Sanskrit (Vyāsa, Kālidāsa, Dhanapāla: v. 11).

61 In actuality, the same kulapati Babbhu who is relating his adventures to Harivikrama on level B is also acting as the kulapati narrating his story to Virasena on level D. 
encountered Candraśrī again, and after returning to his town, he married her. However, soon after the two young lovers were separated again. When the prince returned, he became the king and had a son Amarasena. After many further adventures, the royal family decided to renounce the world. Only Candraśrī was not allowed to become a nun, since she was pregnant. Later, she was taken away by a Vidyādhara and gave birth to a girl, who happened to be named Bhuvanasumdarī. When the princess became an adolescent, the Yakșa Malayamegha looked for a suitable husband for her and during his quest saw Prince Harivikrama, who pleased him. That is why he abducted him and led him in the forest where Bhuvanasumdarī and her mother lived under the protection of the kulapati Babbhū whom the prince saw at present. This is the end of level $B$ with its analepsis of about 7000 verses.

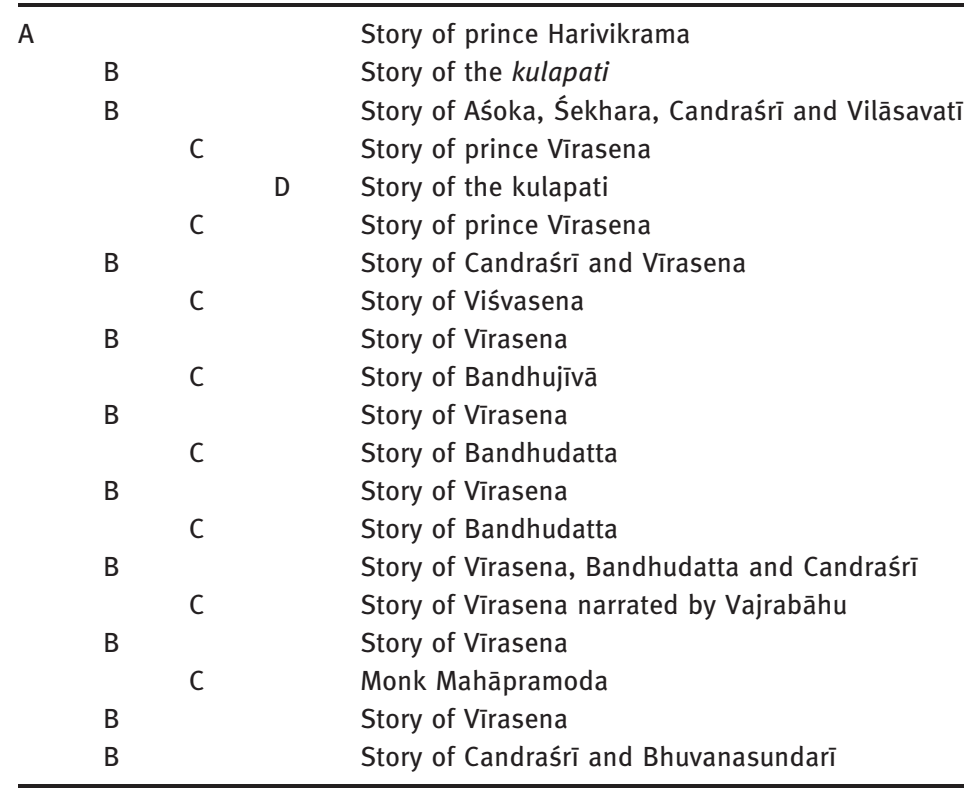

The narrator continues on level $A$ to narrate prince Harivikrama's adventures. Because of the mission the prince had to fulfil for his father, the marriage was delayed. During the prince's absence, Bhuvanasumdarī met a girl who told her story on level $B$. She was a Vidyādharī abducted by the Vidyādhara Cittavega and left in a basket. Bhuvanasumdarī took her place in order to save her. Upon his return, the prince Harivikrama was desperate not to see Bhuvanasumdarī. After several episodes, he found her again, whereupon the couple were married. After enjoying a happy marital life, they met Virasena, now a monk, who told them the 
prior life of Bhuvanasumdarī. Thereupon, they renounced the world and all the protagonists of the novel attained liberation. Thus, it clearly appears that the plot is as complex and as well organised as those of Kādambari or Kuvalayamālā.

As for Dhaneśvara, even if he tells his audience that before writing new poetry a poet fears the comments of evil-minded men in the same manner as the mouse is afraid of the cat, and that he will write a clear text in Prakrit verses with the caressing words one uses for infants, ${ }^{62}$ he actually did not at all refrain from composing a narrative which is, according to A.K. Warder, "perhaps the most complicated ever written (because of the large number of characters with their successive lives and of the usual novel form of a mystery)". ${ }^{63}$ The Jain poet begins on a first level of narration (A) with the two stories of the king Amaraketu who married princess Kamalāvatī and of the merchant Dhanadeva. During one of his journeys, Dhanadeva helped Devaśarman to retrieve the son of a Bhilla king named Supratișțha. Thus, later on, when the merchant was captured by Supratiștha's men, he was soon after treated like a host. Answering Dhanadeva's question, Supratiștha presented himself as the son of a king, whose second wife wanted her own son to become crown prince. That is how he became the chief of the Bhillas. When Dhanadeva took his leave, Supratiștha offered him a wonder jewel and explained on level $B$ how it came into his possession.

This is a very long tale that extends from Chapter 2, v. 225 till Chapter 9, v. 144. One day, Supratiștha heard a cry and found a divine man hampered by snakes. He is the Vidyādhara Cittavega who began to relate his adventure on level $C$ (from Chapter 3, v. 3 to Chapter 8, v. 71). During one festival, he fell in love with Kanakamālā who answered his feelings. But soon after, because of a misunderstanding, her father promised her to king Naravāhana. When Cittavega wanted to commit suicide, he was saved by another Vidyādhara, Cittagati, who consoled him with his own story on level $D$. His sister Citralekhā was married to king Jvalanaprabha but was later on abducted by Jvalanaprabha's brother. During his

62 Surasuṃdarī I, v. 18 : annam ca tassa kīrai paḍhamaṃ ciya patthaṇā khala-jaṇassa| Bīhei kavi-jaṇo jassa mūsao iva biḍālassa \|

For 'clear' the author uses payaḍa (v. 40): cp. also Bhuvaṇasuṃdarī, v. 8945 (phuda-viyada); for 'caressing words' he employs the expression uttānatthā pāiya-gāhāhim laliya-payā, suggesting that there are the same words one uses for an infant. 'Laliya-paya' and laliy'akkhara are the expressions used by Uddyotana (4.18; 5.21). While the first one is used by Dhaneśvara (1, v. 42), the second one is employed by Vijayasiṃha (v. 8945).

63 Warder 1992, vol. VI, § 4719. Warder 1992 gives a detailed summary (§ 4715-4775). The substories of the prior lives of the characters of the novel given at intervals by Jain monks from Chapter 6 to Chapter 15 have not been integrated in the present outline of the story which is meant to present to the reader the constant connections between all characters of the plot in its different levels. 
search for her, he fell in love with the girl he saved from the fury of an elephant, but could not find her the following day. While looking for her, he met Cittavega. This is the end of Cittagati's story on level D. Again on level C, Kanakamālā tried to commit suicide and was saved by Cittavega and Cittagati. While taking the place of Kanakamālā in the bridal procession leading her to marry Naravāhana, Cittagati found the girl he was looking for, Priyañgumañjarī, who narrated her story on level $D$. Together they went to meet Cittavega again and warned him from the fury of Naravāhana. During his flight, Cittavega met a god who gave him a wonder jewel that protected him against Naravāhana. The helpful god, Vibhuprabha, whom he had met beforehand manifested himself again and explained to him how they came to know each other in a previous life. The story is narrated on level $D$. That is the very jewel given by Vibhuprabha that Cittavega offered to Supratisțha who saved him. There ends the narrative on level $C$. The same jewel was now given by him to Dhanadeva. This is the end of the long narrative of level $B$ that had started in Chapter 2.

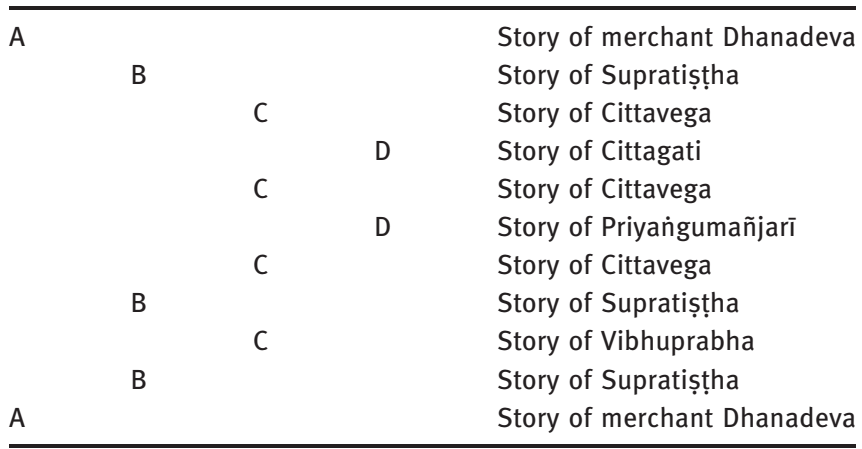

On level A again, after saving Śrīkāntā, Dhanadeva married her. After a journey, Dhanadeva wanted to visit his friend Supratisthha, but he found the village of the Bhillas burnt down. The only survivor, Devaśarman, told him what happened, but did not know what had become of Supratișțha. Later, Dhanadeva and Śrīkāntā had a son. This event made Amaraketu's spouse, Kamalāvatī, a friend of Śrīkāntā, desiring to have her own son. On one occasion, she was taken away by an elephant and brought back by Amaraketu one month later. She told him in a flashback what had happened to her during their separation. She gave birth to a son who disappeared and escaped from the evil-minded Suratha. One day later, in Chapter 11, the porter Samantabhadra found a girl fallen from the sky. She was Surasumdarī, daughter of king Naravāhana, who had been abducted. Kamalavatī took care of her and sent a servant of her age, Hamssikā, to win her trust. 
Surasumdarī related to her in the level B between Chapter XI, v. 189 and Chapter XII, v. 232, that one day she saw a young girl trying to fly. She was Priyamuvadā, daughter of Cittavega, and half-sister of Makaraketu whom she wanted to meet. When Priyamvadā was about to leave, Surasumdarī noticed the portrait she had of Makaraketu and fell in love with him. Later on, she mocked an ascetic woman, Buddhilā, who took revenge by persuading king Śatruñjaya to marry her. Upon her refusal, he besieged the town. Meanwhile, a Vidyādhara Nahavāhana abducted her and placed her in a grove. She ate a poisonous fruit and was saved by Priyamvadā accompanied by Makaraketu. As she was worried about her father, Makaraketu went to assist him, but he did not come back. This is the end of the story Surasumdari narrated to her friend Hamsikā.

One day, the merchant Dhanadeva came back from his journey and narrated to king Amaraketu his marvellous adventures. When the monk Supratiștha became omniscient, king Amaraketu and his wife went to meet him and to ask him about their son who disappeared after his birth. The monk explained everything on level $B$. Makaraketu found his parents again and married Surasumdarī. First she had a son, Madanavega, who was taken out of the palace because he was predicted to cause the ruin of the family. Then she had another son, Anangaketu, who fell in love with Ananggavegā and married her. But since Jvalanavega had already asked her in marriage, he was furious and revealed to Madanavega his real birth so that he would kill his father Makaraketu. Infuriated, Madanavega assaulted his father who was disgusted with the mundane life and renounced the world. All the protagonists of the novel in the end obtained liberation except for Madanavega who was condemned to wander in the cycle of existences. That is why good people should behave according to the dharma.

The structural outlines make it clear that with the exception of Manorama which displays a much simpler structure, heroine 'novels' in Prakrit are characterised by a complex plot and interconnected sub-stories that are akin to Bāna’s project and have their own specific threads of story. ${ }^{64}$ Besides, very long analepses have been inserted by all the Jain authors, as was the case in Kādambarī. ${ }^{65}$ Furthermore, as in Bāṇa's work, the heroine who gives her name to the 'novel' appears very late in the narrative: Kuvalayamālā (3/4: p. 153

64 On the exception which is Maṇoramā see infra. Nivvānalīlāvā also betrays a complex structure, but on the one hand its complexity has limitations (see infra) and on the other hand, the work cannot be assessed in the same way as the other novels since it is seen only through its adaptation, Līlāvatīsāra.

65 Thus over 79 pages (p. 31-110) for Kuvalayamālā ; v. 861 to v. 7899 for Bhuvanasuṃdarī; from Chapter II, v. 1 to Chapter XVII, v. 4 in Jinaratna's epitome of Nivvāṇalīlāvaī; from Chapter 2, v. 225 till Chapter 9, v. 144 for Surasumiarī. 
out of 217 pages); ${ }^{66}$ Bhuvanasuṃdarī (7/8: v. 7822/8945); Surasuṃdarī (3/4: Chapter 11, v. 143/Chapter 16) and Maṇoramā almost at the end (p. 316 out of 337 pages).

If such complex structures undoubtedly demonstrate that the Jain monks wished to produce refined literary compositions that could rival those of renowned predecessors in Indian literature, ${ }^{67}$ did they serve only to show the ingenuity of their authors and to surprise a demanding audience that would be critical of too simple and repetitive scenarios? Or did they contribute to conveying a religious purpose, as seemed to have also been the case in Kädambarìs difficult narrative structures? Indeed, as noted by D. Shulman, the many narrative voices of the text make it easy to lose track of the story, and difficult to ascertain who is actually telling the story and who is listening to it. However, the resulting confusion is a deliberate feature of the emplotment and conveys a message to the audience: the heroes Candrāpīda and Pundarika are not the characters they seem to be, but are actually someone else. ${ }^{68}$ Moreover, since at the same time the heroines Kādambarī and Mahāśvetā remain the same, they fail to recognise the reality of the situation. Thus, while Pundarìka who has become Vaiśampāyana has the same feelings for Mahāśvetā, she does not perceive that he is her former lover and curses him. In the same way, in a passage analysed by D. Shulman, Patralekhā reports to Candrāpīda who has left her alone without a word in order to see his father, how Kādambarī has expressed her despair, saying that while she is the same and he is the same, the situation has changed. ${ }^{69}$ Jain authors could not but be interested in such a depiction of ignorance and passionate misconduct in a world of illusions, as it fitted their own beliefs in the futility of the circle of existences.

As a consequence, they used the same devices of analepses, nonlinearity as well as a system of characters in order to convey their ideals of monastic life in their heroine 'novels'. Thus, in Surasumdarī, Dhaneśvara introduces a very long analepsis told by Supratiștha, a prince who has lost his kingdom and become the chief of the Bhillas. In this long passage comprising about half of the entire text on level B (including a long level $\mathrm{C}$ which in turn comprises several levels D), there are five main narrative voices:

66 The history of Kuvalayamālā occurs in the first part of Uddyotana's novel (pp.1-217) which in the edition of A.N. Upadhye (Upadhye 1959) comprises a second part (pp. 217-284). See Chojnacki 2008b: 451.

67 The authors who are mentioned are both of Prakrit literature and Sanskrit literature. For Bhuvaṇasumdarī see supra n.60; for Kuvalayamālā, see Chojnacki 2008a: 36-37; Uddyotana is the only one to precisely define the stylistic devices which he would employ in his Kuvalayamālā (Chojnacki, 2008a: 37-38).

68 Cf. Shulman 2014: 278.

69 Cf. Shulman 2014: 296-297. 
1. Supratiștha narrates a story to Dhanadeva (B)

2. Cittavega to Supratișțha (C)

3. Cittagati to Cittavega (D)

4. Priyañgumañjarī to Cittagati (D)

5. Vibhuprabha to Cittavega (D)

This means that, beside himself, Supratiștha represents four other narrators three male (Cittavega, Cittagati, Vibhuprabha) and one female (Priyañgumañjarī). Dhaneśvara even enhances the difficulty, when in a paronomastic play he gives these two Vidyādharas names beginning with Citta- ${ }^{70}$ Indeed, as D. Shulman has noted for Kādambari, this structure is confusing for the audience, but in case of Surasumdari, it is also very efficient. As a matter of fact, the purpose here is twofold. On the one hand, not only the merchant Dhanadeva but also the audience of Dhaneśvara's novel are shown that human birth, difficult to obtain, is the best way to reach liberation and that one should not waste it. On the other hand, the Jain author wants to prove to the audience that one should not envy the destiny of the marvellous beings who can fly and enjoy many pleasures, since Cittavega and Cittagati also suffer immensely from the pangs of love, hate and other associate passions in the terrible cycle of existences (3, v. 3-6; 5, v. 52; 8, v. 106) and have to be able to become human beings (4, v. 74) in order eventually to be liberated. That Dhaneśvara has such an intention is further indicated by the vocabulary he uses in this long analepsis: thus there are verbs indicating emotions, qualifying attributes or adjectives ${ }^{71}$ suggesting the trouble of minds affected by a passion and its extreme degrees - amorous ecstasy (3, v. 123; passim); despair (4, v. 106; 4, v. 149-176). And at the end of Cittavega's narrative, in case the audience would still have any doubt about the message of the analepsis, Dhaneśvara gives a clear reminder with the conclusive straightforward verses with which Supratișțha addresses Dhanadeva. It reads as follows:

70 Many other names have similar beginnings or endings that suggest the assimilation between one character and his double (for instance Dhanadeva; Dhanavāhana; Dhanavai) or the intended confusion: for instance Vihuppaha, Vijjuppaha and Sassippaha; Caṃdappahā and Caṃdarehā; Amarakeu, Samarakeu, Mayarakeu and Ananggakeu; or Naravāhana and Nahavāhana.

71 E.g. - sad (3, v. 147; 4, v. 22; 6, v. 14); frozen in place because of love (3, v. 172); exhaling long sighs (3, v. 186; 6, v. 11); sobbing (6, v. 12); having eyes full of tears (3, v. 215); having the heart filled with joy (4, v. 2; 7, v. 88; 7, v. 139); unconscious (4, v. 245; 9, v. 92); frightened (5, v. 103; 5, v. 196; 6, v. 152; 7, v. 3; 8, v. 5); suffering (2, v. 229; 8, v. 67); trembling (5, v. 110; 5, v. 159; 6, v. 175; 9, v. 32); furious: 7, v. 231; 8, v. 30; 9, v. 24; 9, v. 48) - and nouns - cries or laments (2, v. 231; 4, v. 127 ; 8, v.15; 8, v. 62); burning heart (3, v. 224; v. 232); harsh words (5, v. 108; 6, v. 172); anxious thoughts (passim). 
They know deep suffering in this world and in the world beyond, The men who are deluded by passion and do not distinguish right from wrong. For all souls, the first cause of unbearable spiritual and bodily pains In this world and in the world beyond is the terrible passion. ${ }^{72}$

In Bhuyanasumdari, the main action is no longer in the heavenly realm, as in Surasumdari, but in the human world. Therefore, even though the number of narrative voices is similar in the two works, the analepsis takes a different turn.

1. The kulapati narrates a story to prince Harivikrama (B)

2. Brahmin Govardhana to Vilāsalakșmī, Candraśrī’s friend (C)

3. The kulapati to prince Virrasena (D)

4. King Viśvasena to prince Virrasena (C)

5. Vidyādhara Vajrabāhu to princess Candraśrī (C)

6. Monk Mahāpramoda to prince Vīrasena (C)

Indeed, Vijayasimha does not show here the illusion in the world of gods, but he insists on the initiatory life of the heroes. In effect, the analepsis brings to the ears of prince Harivikrama the spiritual progression of his double, Virrasena, and all the narrative voices converge toward this aim. As a matter of fact, there are several speakers, but one main listener: Virasena within the analepsis and his double Harivikrama in the frame story. Thus, when in the discourse of the Brahmin (narrated by the kulapati to Harivikrama), the kulapati presents himself to prince Virasena, he actually explains at the same time to prince Harivikrama who he is. The other listeners are also connected to Virasena, since his conduct is the subject of the discourse addressed to Candraśrī, who is destined to marry Vìrasena, and to Vilāsalakșmī, Candraśrī’s friend, and they can see his spiritual progress. Consequently, the analepsis as a whole conveys to Harivikrama and the audience the necessity to practice the dharma. It is the same convergence of narrative voices that occurs in Uddyotana's Kuvalayamālā, since the religious discourses addressed to the five souls - two of them being Sāgaradatta and Kuvalayacandra - (C) enlighten as well King Purandaradatta (B) and Prince Kuvalayacandra (A). ${ }^{73}$

72 Surasuṃdarī 8, v. 74-75: acchau tā para-loge iheva pāvimnti garuya-dukkhāiṃ |rāga-vimohiya-cittā kajjākajjaṃ ayāṇaṃtā || 74 ||sārīra-mānasāṇam dūsaha-dukkhāṇa kāraṇaṃ paḍhamaṃ |iha para-loe ghoro rāgo cciya sayala-jīiānam || 75 ||

73 On Uddyotana’s long analepsis, see Chojnacki 2008a: 54-56. 
1. A monk (Sāgaradatta) narrates a story to Prince Kuvalayacandra

2. Monk Dharmanandana to king Purandaradatta

3. Jina Dharma to the five souls in the preaching assembly

4. A girl to Sāgaradatta

But the element that renders the structure more complex is that Uddyotana decided to enact several lives of his characters. In this case especially, the nonlinear plot used by Bāna proved to be efficient for both the aesthetic and the religious project. As a matter of fact, while Uddyotana chose to surprise his audience by revealing the name of the narrator of the analepsis only at its very end, he avoided the rather mechanical scheme of a linear presentation and highlighted one of the many lives lived by the characters. Thus he introduced firstly the third life in which they were already devoid of evil passions but still needed to be properly educated in order to be on the right path toward liberation. It was also edifying for his audience, since they could see both what had originated the present life and which type of successful future the present life would bring them. But it required Uddyotana's ingenuity: to have begun with the last life, as Jineśvara did in his Nivvānalīlāvaī, did not produce the same edifying effects. ${ }^{74}$

In the complex plot of Kādambarī, Bāna has also used the device of previous existences, although it remained rather peripheral and limited to the male characters. On the contrary, for Jain authors, the motivation of the destiny of such and such character by the design of the past actions was very common in the short edifying stories, and this articulation was the source of many sub-stories that were consequently only tenuously connected to the main story. So the question at stake for the Jain poets who wanted to compose literary works in the vein of a masterpiece such as Kādambari was how to integrate skilfully the prior lives for their religious purpose. The issue was resolved in various ways. Indeed, Uddyotana did not break with the Jain tradition as taken up for instance by his master Haribhadra even in a long narrative such as the Samaräiccakaha ${ }^{75}$ But he deftly used the non-linear plot in order to highlight them. Thus, while he first presented the life of Kuvalayacandra in a courtly atmosphere and his adventure in the forest with the lion, the divine man and

74 Since there is no vivid spiritual progression to which the audience can identify itself.

75 Haribhadra made use of the extended narrative space and presented one good soul and one bad soul affected by all the passions through nine of their multiple existences. Indeed, the message is as clear as in the short stories: the Brahmin Agniśarman plunges deeper and deeper in the world of evil (Prince Ānanda, housewife Jvālinī, housewife Dhanaśrī, Prince Vijaya, housewife Lakṣmī, Prince Viṣeṇa, Vidyādhara Vānamantara, Caṇḍala Giriseṇa), while Prince Guṇasena (King Siṃha, Minister Śikhin, Businessman Dhana, Prince Jaya, Businessman Dharaṇa, Prince Sena, Prince Guṇacandra, Prince Samarāditya). 
the monk, he created surprise among his audience at the end of the analepsis narrated by the monk Sāgaradatta. As a matter of fact, it is at this point that one understands that Sāgaradatta, the prince, the divine man and the lion are actually four of the five souls (the last one being the princess Kuvalayamālā) who had suffered from evil passions in a prior life (cf. Table 3) and whose spiritual progress would be fulfilled in a next destiny. The monk (Sāgaradatta) who speaks to Prince Kuvalayacandra is the soul of the greedy one (Lobhadeva), the god accompanying him has been previously the voluptuous Mohadatta and the lion has been the violent Caṇdasoma. ${ }^{76}$ Kuvalayacandra himself has been the proud Mānabhața and he receives from the monk the mission to marry and awaken Princess Kuvalayamālā who has been the treacherous Māyāditya. ${ }^{77}$ By doing so, not only does Uddyotana create seductive, lively and plausible characters, but he also takes the opportunity given by the space of the 'novel' to give a central role to a set of five embodied passions and to teach their obnoxious results, but also the possibilities to thwart them. One sees again all these five characters live another life at the end of which they reach liberation. ${ }^{78}$

Table 3: Two lives of Kuvalayamālä's five souls.

\begin{tabular}{llll}
\hline & Life 1:embodied passion & Nickname of the archetype & Life 2:main character \\
\hline Anger & Brahmin Bhadraśarman & Caṇạasoma & lion \\
Pride & Vassal Śaktibhața & Mānabhața & Kuvalayacandra \\
Deceit & Businessmen Gañgādityaa & Māyāditya & Kuvalayamālā \\
Covetousness & Businessman Dhanadeva & Lobhadeva & Sāgaradatta \\
Delusion & Prince Vyāghradatta & Mohadatta & god \\
\hline
\end{tabular}

While Jineśvara simply enlarged Uddyotana's model by doubling the number of souls suffering from passions, ${ }^{79}$ Vijayasimha and Dhaneśvara tried to adapt the

76 Kuvalayamālā 110.4-9: āsi Lohadevābhihāno puṇo saggammi Paumappaho devo tatto vi esa Sāgaradatto tti | imaṃ ca dațthūṇa ciṃtiyam mae 'aho je uṇa tattha cattāri aṇne te kahim sampayaṃ' ti cimtayamto uvautto jāva dițtham | jo so Caṇdasomo so mariūna Paumacaṃdo samuppaṇno | tatto vi saggāo caviūna jāo Viṃjhāḍaīe sīho tti | Mānabhaḍo mariūṇa Paumavaro jāo | tatto vi caiūṇa Aojjha-puravarie rāiṇo Dạ̣havammassa putto kumāra-Kuvalayacaṃdo tti | Māyāicco vi mariūna Paumasāro | tatto vi caviūṇa dakkhināvahe Vijayā-ṇamāe puravarie raino Mahāseṇassa duhiyā Kuvalayamālā jāya tti (Chojnacki 2008b: 339).

77 For a translation of the stories, see Chojnacki 2008a: 170-262.

78 This is the second part of Uddyotana's heroine 'novel': Kuvalayamālā 216.13-280.16 (Chojnacki 2008b: 604-766.

79 Beside stories on the five passions (anger, pride, deceit, covetousness, delusion), Jineśvara included in his 'novel' another set of five stories embodying the effects of the five organ senses: touch, taste, smell, sight, hearing: cf. Fynes 2005: 465-523 and Fynes 2006: 29-269. 
pattern of the prior lives inside the complex frame of their own 'novels'. Thus Vijayasimha reduced the explanations of the prior lives for two main characters, Vìrasena, the double of Harivikrama, and Bhuvanasumparī, and placed them at two major points in the text: for Virasena, they are related just at the end of the analepsis so as to better impress Harivikrama and the audience; for Bhuvanasumdarī, they occur just before her ordination together with her husband. ${ }^{80}$ As for Dhaneśvara, who has the most complicated set of lives, he felt the need to enlighten his audience as to who was who at different intervals in his 'novel' for aesthetic and religious reasons. ${ }^{81}$ As a matter of fact, on the one hand, just as he motivated the episodes of the novel in the manner of a gifted storyteller, ${ }^{82}$ he also wanted to motivate, as the omniscient narrator can do, the relations between all the most important characters of his 'novel'. On the other hand, one can also see how the riddle of the connections between the characters and the events of their life is gradually solved during the 'novel' according to the growing level of knowledge the various speakers possess. ${ }^{83}$ Thus the first narrator to give a clue about past lives is Priyangumañjarī, a princess who on a key-occasion remembers her past life (Chapter 6); the second narrator is the god Vibhuprabha who knows by his clairvoyance the relations he had with Cittavega (Chapter 8); as for the other two, they are omniscient monks: Ghanavāhana (Chapter 9) and the famous Supratiștha (Chapters 14 and 15), who narrated the long analepsis. Thus, all of them aim at highlighting by their discourses the lives of main characters from the frame story of the 'novel' and at explaining to them who every character actually is. For instance, king Amaraketu and his wife Kamalavatī learn how their son, Madanavega, has inherited from his past lives an otherwise inexplicable hatred, and this is the cause of their renunciation of the world. Once the illusion of the samsāra and the destructive ignorance are destroyed by the omniscient teachers and all the

80 Cf. Bhuvaṇasuṃdarī v. 8806-8899.

81 The explanations occur in Chapters 6, v. 133-250; 8, v. 101-250; 9, v. 18-62; 14, v. 98-250; 15, v. 198-224: cf. Warder 1992, vol. VI: § 4732, § 4737; § 4739; § 4755; § 4758.

82 In Surasuṃdari, Dhanadeva helps Devaśarman out of compassion and saves the child of the chief of the Bhillas who was under his responsibility. As a consequence, later on, when he is attacked by Bhillas and led to their chief, Supratișțha, he is treated as a host thanks to Devaśarman who has explained to Supratișțha who Dhanadeva was (1, v. 34-69). In a similar manner, the hatred of the villains is on several occasions logically motivated: thus, Jvalavega, an evicted lover unveils to the exiled Samaraketu the secret of his princely birth and uses him to be revenged (16, v. 124-126).

83 Priyañgumañjarī remembers (6, v. 142) that she has been Vasumatī, then Candraprabhā before her birth as Priyangumañjarī. It is only in Chapter 14, v. 98, that the omniscient Supratișța tells her that she has also been Sarasvatī in a prior life. 
Table 4: The lives of Surasumpdarîs main souls.

\begin{tabular}{lllll}
\hline Soul & Life 1 & Life 2 & Life 3 & Life 4 \\
\hline 1 & Lakșmī & Sulocanā & Svayaṃprabhā & Surasuṃdarī \\
2 & Mandana & Kaṇakaratha & Vibhuprabha & Makaraketu \\
3 & Nimnaya & Subandhu & Kālabāṇa & Madanavega \\
4 & Malhana & Dhanapati & Candrājuna & Cittagati \\
5 & Sarasvatī & Vasumatī & Candraprabhā & Priyañgumañjarī \\
6 & Mohila & Sumangala & & Suratha \\
7 & Candana & Dhanavāhaṇa & Vidyutprabha & Cittavega \\
8 & Saṃpadā & Anañgavatī & Candralekhā & Kaṇakamālā \\
\hline
\end{tabular}

threads joined together, the audience can see through the lives of eight souls during four lives, as can be seen in Table $4 .{ }^{84}$

It remains to see why Jain monks adopted the complex structure of Bāna's Kädambarī especially for their heroine 'novels' in Prakrit. In religious Jain literature, edifying sermons, moralising maxims and vivid short stories recurrently expressed that women and love were an obstacle to liberation. For instance, Dhaneśvara says that women are like guñjā-berries, beautiful outside but poisonous inside; ${ }^{85}$ he also shows how one of his characters, who was very attached to the love of his wife, was first ordained with her and had to be educated afterwards. ${ }^{86}$ Such ideas and motifs are in keeping with the canonical teaching of the fallacious seduction by women as illustrated by the parable of princess Malli who created a statue that looked like her but was full of rotting food in order to discourage the pretenders who all came to marry her because of her external beauty. ${ }^{87}$ It is therefore plausible that Jain authors found in the lengthy and complex structure of the heroine 'novel' set up by Bāna a most convenient means for both seducing the audience and teaching Jain values. Indeed, the fact that the heroine of the 'novel' appears very late in the narrative space was used to change the quest for love into a quest for religion. For instance, when Uddyotana begins with a courtly scene in Ayodhyā and with the life of a prince, the audience is led to think that it will be a novel dealing with several feminine conquests. But the narrator soon deceives his audience and takes the characters toward unexpected

84 On several occasions, Dhaneśvara points out how a fact can be wrongly interpreted because of ignorance: for instance, when the painter laughs in seeing the king Amaraketu fainting in front of the portrait of a princess (1, v. 97). The ignorant people trounce him, because they think he is mocking them (1, v. 99). But in reality, he laughs out of joy since he knows that it is the sign that the king is the right husband for the princess (1, v. 107-159).

85 Cf. Surasumdarī 8, v. 151.

86 In the same way as the well-known example of Nala and Damayantī in the Jain versions.

87 Cf. Nāyadhammakahāo, 8. Malli and Schubring 1978: 24-35. 
adventures. And thanks to a monk who narrates in an analepsis the prior consequences of passions, Kuvalayacandra receives a double mission: to marry the beautiful princess Kuvalayamālā but also to awaken her to the Jain dharma. ${ }^{88}$ Besides, on several occasions, authors use a non-linear frame and several narrative voices in order to teach how love is a source of delusion. Thus, the sub-story of a beautiful but flirtatious prince, Kāmagajendra "Elephant of love" is an example where the narrative complexity serves a religious purpose. One first sees that Kāmagajendra's wife is desolate because her husband is absent. The latter comes back not long after and narrates his adventures. He had gone with two Vidyādharīs in order to save their friend, Bindumatī, who was dying of love for him. But she died before their arrival. Out of despair, the young Vidyādharīs leapt into the pyre. Kāmagajendra wanted to take water in a well in order to make a libation for them, but soon after he saw himself in another country. He was then awakened by the Jina Simmandhara who explained to him all the divine illusions he had seen. After narrating this tale to the queen, he told her that he was disgusted by all these illusions and wished to renounce the world. Therefore, he went to see the Jina Mahāvīra who was just telling Kāmagajendra's adventures to the assembly of devotees. Because of the non-linearity of the events in the story and because of the narration of the story to several listeners - the queen, the assembly of Sīmandhara, the assembly of Mahāvīra, Kāmagajendra himself and the audience, it is easy to lose track of who is who. ${ }^{89}$ Thus, this is a perfect example to show the illusory vanities of the amorous passions. With Uddyotana, it is not a random but a conscious intention, since he operates in the same way for the story of Mohadatta, the embodied delusion, who fell in love with his own sister, whereas their father did not recognize the young lady he once ardently loved and fell in love with the daughter she had from him. ${ }^{90}$ It is also significant that in her prior existence, Kuvalayamālā was the treacherous Māyāditya, whose story is also as twisted as his character. ${ }^{91}$

Consequently Jain heroine 'novels' modelled on Kādambarī were given by their authors such complex and curved structures with the conscious intention of denouncing indirectly the delusions of love and the obstacles they constitute on the way to liberation. In short, the beautifully complex structures of the 'novel' illustrated on a macro-level what the theme or the parable effected on a micro-level in order to teach both the vanities of the world and the salutary

88 Cf. Kuvalayamālā 111.22-23: Chojnacki 2008b: 342.

89 Cf. Chojnacki 2008a: 69.

90 Cf. Chojnacki 2008b: 254-255.

91 As for Jineśvara, he reproduced a similar complex plot for the sub-story of princess Surasuṃarī: cf. Fynes 2006: 382-489. 
practice of the dharma leading to liberation. If the Jain monks used a deceptive plot in their heroine 'novels' and seemed to present the stories of heroes rather than of heroines, at the same time, however, the titles of the works truly suggest in which direction the 'novel' is to be read. Kuvalayamāla is the 'garland of nympheas' for Kuvalayacandra, the prince who is 'the moon awakening the nympheas'; Bhuvanasumdari is the 'beauty of the human world' wherein one can be liberated; Nivvānalīlāvaì is the 'frivolous leading to liberation'; Surasumdari is the illusory 'beauty of the world of gods' and Manoramā is the 'charming' way to get education in the Jain dharma. Can further evidence suggest that, while taking inspiration from Bāṇa's Kādambarī, Jain monks also created their own tradition of complex religious heroine 'novels' in Prakrit? And if so, why did this literary movement end after a period of four centuries?

Not only did Uddyotana clearly cite Bāna as one of his predecessors, but he also played on several occasions with the model of Kädambari either to create surprise or to criticise unlikely events or practices contrary to Jain values. Thus, while he takes up the scene during which the queen is desperate not to have a son, he plays with the expectations of his audience. Indeed, it is not the queen as is the case in Kādambari who accomplishes various rituals in order to obtain a son, but rather the king who propitiates a deity for this purpose. ${ }^{92}$ Moreover, he presents in a sub-story a heroine, Sumdari, who is inconsolable over the loss of her husband and embraces him in the hope that he will live again, Uddyotana has probably in mind the well-known episode of the embrace of Kādambarī. But, while Bāṇa depicts the beloved Candrāpịda coming back to life in his previous body, Uddyotana shows that the embrace of Sumdari cannot prevent the body from decaying and only results in the mockery of the villagers. ${ }^{93}$ As for later writers of Prakrit heroine 'novels', they mentioned neither Bāṇa nor Uddyotana, but it is clear from their works that they knew both authors. As a matter of fact, many motifs and scenes that are taken over by the authors of the heroine 'novels' clearly show an interrelation between those works. Thus, in Bhuvanasumiarī as in Kuvalayamālā, the king expresses his joy, when his wife has guessed his thought and said aloud that it would be time for them to renounce the world without delay. ${ }^{94}$ In Surasuṃdarì as in Nivvāṇalīlāvaī, an evil female ascetic who had been rejected by a princess or a queen makes a king fall in love with her in order to take her revenge. ${ }^{95}$

92 Cf. Kuvalayamālā 14.4-31: Chojnacki 2008b: 64-68.

93 Kuvalayamālā 224.26-225.32: Chojnacki 2008b: 631-634.

94 Kuvalayamālā 214.19-33: Chojnacki 2008b: 599-600; Bhuvaṇasuṃdarī v. 8761-8771.

95 Surasuṃdarī 12, v. 66-80; Līlāvatīsāra VII, v. 49-50. 
The numerous common motifs also point to the fact that the parallel episodes are not just copied from one work to the other but adopted with variations. Take for instance the motif of the queen desiring a son. In Bhuvanasumdari, the Jain monk explains to the queen Vijayavati how to obtain a son through the propitiation of the goddess Ambā; in Surasumdari, in answer to the longing of the queen Kamalā, the king prays to the Jina and fasts for three days to propitiate a god, who explains to him that he will become the queen's son; in Manoramā, after the queen has propitiated a Yakṣa, then the goddess Candị, and has tried several other means to obtain a son, but all in vain, omens eventually arise predicting the birth of a son. ${ }^{96}$ Another scene from Kädambari appears with some changes in Kuvalayamālā and in Bhuyanasumdarī. The prince Candrāpīda, who is thirsty because of a long journey, searches for a place with fresh water. He follows the wet tracks of elephants and the movements of birds and arrives at the lake Acchoda with many birds, fish and flowers "which was most beautiful and gratifying to the sight”. On the southern bank of this lake, he sees many beautiful, phallus-shaped idols of Śiva and not long after he discovers a holy shrine sacred to the divine Siva. ${ }^{97}$ But the scene changes from Kuvalayamālā to Bhuyanasumiarī: while the prince Kuvalayacandra sees two beautiful young ladies, the prince Harivikrama contemplates a temple dedicated to Lord Sāntinātha. ${ }^{98}$

While several motifs thus indicate the aesthetic influence of Bāna, many other religiously oriented motifs are clearly inherited from Kuvalayamālā. For instance, in Nivvānalīlāvaī, Jineśvara introduces, as did Uddyotana, the motif of a painted scroll and imagines that a god describes all the manifestations of misery and happiness. ${ }^{99}$ Besides, the attack of the Bhillas in Surasuṃdari Surasuṃdari is reminiscent of the episode in Kuvalayamālā, but while in the latter work, the chief of the Bhillas feels remorse as soon as he hears prince Kuvalayacandra uttering the prayer to the five supreme beings, in the former, he does not fight at all, since he learns how the hero has saved his son earlier. ${ }^{100}$ The same scene of the effect of the prayer to the five supreme beings occurs with some variation in Bhuvanasumdari, but the surprise is that while in Kuvalayamālā, the anti-hero is the prince Darpaparigha, in Bhuvanasuṃdarī, he is a Vidyādhara. ${ }^{101}$ Two other examples will suffice. In Nivvānalīlāvaī, the story of Yaśoravi evinces many similarities with the story of Lobhadeva in Kuvalayamālā: a dialogue between

96 Bhuvaṇasuṃdarī v. 947; Surasuṃdarī 10, v.41-53; Mạ̣oramā 6.17-7.27.

97 Kādambarī 376-391: Kale 1968: 166-172.

98 Kuvalayamālā 113.31-115.26: Chojnacki 2008b: 349-353; Bhuvanasuṃdarī v. 2284-2344.

99 Kuvalayamālā 185.13-193.31; Līlāvatīsāra 15.15-104: Fynes 2006: 494-515.

100 Kuvalayamālā 136.8-137.15: Chojnacki 2008b: 403-405; Surasuṃdarī 2, v. 4-54.

101 Bhuvanasuṃdarī v. 2779-2783. 
the merchants about the products of their trade, the transformation of the deceived merchant into a Vyantara who creates a dreadful tempest and the prayers of the seamen. ${ }^{102}$ In Manoramā, Vardhamāna includes an episode that is reminiscent of relations between the good friend Thānu and the bad friend Māyāditya in Uddyotana's Kuvalayamālā. But, while in both stories, the bad friend pushes his friend into a well in order to enjoy the riches all alone, the reaction of the virtuous character varies. In Kuvalayamālā, Thānu is so innocent that he does not want to believe in his friend's villainy; in Manoramā, in contrast, Samudradatta fully realises what has happened, but, since he wants to save his life, he pretends that he has slipped and that there are many jewels in the well. ${ }^{103}$

Not only were Uddyotana's successors skilled in adapting episodes and creating new situations, but they also enriched the complex form of the Jain heroine 'novel' in several ways. In fact, Vijayasiṃha and Dhaneśvara understood that Kuvalayamālā's long Jain sermons interrupted the narrative, so they shortened or omitted them and rather used other devices in order to bring their religious message. As it was suggested earlier with the analysis of the analepses, Vijayasimha refined the model of the initiatory 'novel'. Thus, the prince Virrasena is at first irascible but gradually becomes compassionate toward other beings. That is how he can adopt the vows of a layman and learn the prayer to the supreme beings. ${ }^{104}$ Not only does this formula protect him, but it reminds him of benevolence when he hears his enemy pronouncing it. ${ }^{105}$ After his meeting with the omniscient teacher Mahāpramoda, Vīrasena initiates others in the Jain dharma, for instance his father whose dream he is able to interpret. ${ }^{106}$ In a similar way, for Harivikrama, who is the double of Virrasena, the meeting with princess Bhuvanasumdarī has become an initiatory journey that led both of them to the liberation from the cycle of existences. ${ }^{107}$ As for princess Bhuvanasumdarī, she was predisposed to be a virtuous heroine, since she had spent her childhood and adolescence in doing pious actions in a forest. ${ }^{108}$ Dhaneśvara refined the narrative illusion of the marvellous 'novel' and, in the tradition of Haribhadra, insisted on the aberrant relationships that souls can have from one existence to another. For instance, without knowing it, Lakșmì becomes the illegitimate wife of Kanakaratha who was his husband Maṇana in

102 Kuvalayamālā 64.27-69.7: Chojnacki 2008b: 222-233; Līlāvatīsāra VI.1-145: Fynes 2005: 367-391.

103 Kuvalayamālā 56.21-64.26: Chojnacki 2008b: 201-222; Maṇoramā 142.10-17.

104 Bhuvaṇasuṃdarī v. 2585.

105 Bhuvaṇasuṃdarī v. 2783.

106 Bhuvaṇasuṃdarī v. 7428.

107 Bhuvaṇasuṃdari v. 7900-8945.

108 Bhuvaṇasuṃarī v. 7822-7891. 
a previous life and because of his ignorance, Haridatta would like to marry Priyañgumañjarī who was previously his daughter Ananggavatī. ${ }^{109}$

However, because of the difficulty of the genre, not all the authors were able to master the model in the same way. A first subtle degeneration appears in the shorter Surasumdañ, inasmuch as Dhaneśvara - voluntarily or not - does not master in the same way the means of the kārya. Thus, he does not leave much space for descriptions or for thoughts of his characters but insists on a simple and efficient style of narration. The limits of the model and the changes are much more visible in Jineśvara's Nivvānalīlāvā̄ and in Vardhamāna's Maṇoramāa. Indeed, as far as we can judge by the summary, Jineśvara wants to do too much and unfortunately makes the wrong literary choices by unnecessarily complicating the model or by outrageously simplifying it. Thus, on the one hand, the author of Nivvānalì $\bar{a} v a \bar{l}$ presents the illustrations of ten passions instead of the five dealt with by Uddyotana, while he also describes three lives for each of the passionate souls and adopts a non-linear structure in these archetypical stories. On the other hand, he begins with the last life of his main characters and does not let them experience another further existence in front of the audience once they are educated; and especially, instead of waiting to present the heroine Lìlāvaì as the object of an amorous and spiritual quest as in Kuvalayamāla , he makes her marry king Vijayasena at the beginning of the 'novel'. ${ }^{110}$

As for Vardhamāna, who is the last Jain author to compose a long narrative named after a heroine, the 'charming' Manoramā on the model of Bāna's and Uddyotana's 'novels', he does not master in the same manner as his predecessors the structure of a complex unitary narrative. Indeed, the first chapter of his work recalls the model of Kuvalayamāla with a scene at the court of king Narakesarin and of his wife Priyangumañjarī and with the birth of a son, Prince Narasimhha, who later marries Rambhāvali, and it also presents a complex structure with an integrated analepsis. In the next three chapters, however, Vardhamāna appears not to care any longer for the intertwined plot of the 'novel'. He takes over a linear structure and one can see, as in Haribhadra's Samaräiccakaha, the progression of the main characters in their successive lives. King Narasiṃha and his wife Rambhāvalī become in the second chapter the merchant Samudradatta and his spouse Ratnāvalī, in the third chapter, a Vidyādhara couple Bhūrivasu and Ratnaprabhā, and in the fourth chapter the king Surrasena and his wife Manoramā. But, on the one hand, the role of the main characters and the space they occupy is very limited. Indeed, the main narrative which comprises a total of only 46 of the 339 pages of the 'novel' is

109 Surasuṃdarī 8, v.192-193; 15, v. 35: Warder 1992, vol. V: § 4737; § 4756.

110 Lìlāvatīsāra I.145-155: Fynes 2005: 54-59. 
distributed as follows: 20 pages out of the 138 pages of the first avasara (that is about $15 \%$ ), 7 pages out of the 105 pages of the second avasara (that is about $6 \%$ ), 5 pages out of the 65 pages of the third avasara (that is about $7 \%$ ) and 14 pages out of the 29 of the last avasara (45\%). And on the other hand, while Haribhadra integrated prior lives of the characters in order to provide a motive for their actions and their feelings in a present situation, Vardhamāna is instead preoccupied with giving illustrative edifying stories that are if at only very loosely connected to the main narrative: 15 sub-stories in a second level of narration for the second chapter, 29 in the third. So the complex wedding garland of Kuvalayamālā has merely become in Vardhamāna's hands a charming bouquet of short edifying stories.

At the end of this survey, it appears that the pioneering work of Uddyotana inspired by the much admired Kādambari of Bāna, has, in the same manner as did Bhavabhūti and Abhinanda for the Pāla poets, ${ }^{111}$ acted as an intermediary for the creation over a period of four centuries of a new literary school of Jain heroine 'novels' that had aesthetic and religious aspirations. Thus, three of the four successors of Uddyotana managed to compose their work as wedding garlands whose flowers are artistically intertwined and arranged, and to convey at the same time their religious message. Even Vardhamāna, who opted in the course of his project for the easier form of the bouquet that was usual in Jain edifying narratives, has kept a complex structure for the first chapter of his work. This shows $a$ contrario that the complexity of the plot was an expected component of the Jain heroine 'novels', but as regards form, style and content, they appear to have been left to the taste and the orientations of the authors, who could thus create their own innovations. If Vijayasimha and Vardhamāna both opt for the kāvya style and structures in their works, the former chooses to write his entire 'novel' in a verse typical of Prakrit literature, while the latter continues the genre of the campū inherited from Uddyotana. And while Dhaneśvara also composes his 'novel' in $\bar{a} r y \bar{a}$ verse, he decides to write in a simpler narrative style without any descriptive or dialogical pause typical of the refined kārya style. Besides, according to their literary project, all of them also chose different options to provide either a realistic or marvellous content of their work.

Consequently, the complex unitary plot of the Jain heroine 'novels' as well as the dominating role of narration and the literary maturity of their authors may

111 Cf. Innovations and Turning Points 2014: 355; Tubb 2014b: 355-394. Bhavabhūti is recognised as belonging in the same way as Vakpatirāja to the legacy of Bāna (both cited as such by Rājaśekhara and Soḍdhala: Tubb 2014b: 361-363) and to have influenced Abhinanda for his lighter Vaidarbhī style (Tubb 2014b: 358-359). In the same way, Bhavabhūti seems to have been one of the sources of inspiration for Dhaneśvara (cf. Warder 1992, vol. VI: §4769). 
entitle them to be labelled as novels, if it is accepted that novels can be either marvellous or realistic in content. Then, while Bāna's Kādambari, although in prose, appears to be a 'prose poem', because of the importance it gives to descriptions and to a vision of the world, it would be adequate to designate the Jain narratives named after a heroine as 'poetic novels' if one takes into account that they are partly or totally versified but place the narration in the foreground. Anyway, this school of Jain 'novels' no doubt constitutes a significant moment in the literary production of medieval India and as such deserves fully to be reckoned among masterpieces in histories of Indian literature.

\section{Bibliography}

\section{Primary sources}

Udayasuṃdarīkathā of Soḍḍhala, ed. C.D. Dalal and E. Krishnamacharya, Baroda: Central Library, 1920.

Kharataragacchabṛhadgurvāvali, ed. by Jinavijaya Muni, Bombay: Singhi Jain Series, 42, 1956. Kādambarī of Bāṇa, ed. P.V. Kane, Bombay: Nirnaya Sagar Press 1911; ed. S.R. Sharma, Varanasi: Chaukhamba Surbharati Granthamala, 41, 1979; translation by M.R. Kale, Bombay: Motilal Banarsidass, 1968.

Kuvalayamālā of Uddyotana, ed. A.N. Upadhye, Bombay: Singhi Jain Series, 45, 1959.

Tilakamañjarī of Dhanapāla, ed. by Pandit Bhavadatta Sastri, Bombay: Kavyamala, 1903; ed. N. M. Kansara, Ahmedabad: L.D. Institute of Indology, 1991.

Nāyadhammakahāo, ed. by Muni Jambūvijaya, Bombay: Shri Mahavira Jaina Vidyalaya, 1989. Bhuvanasuṃdarī = Siribhuyaṇasuṃdarīkahā of Vijayasiṃha, ed. by Vijayaśīlacandrasūri,

Ahmedabad: Prakrit Text Society Series, 39, 2000.

Manoramā of Vardhamāna, ed. R.K. Pagariya, Ahmedabad: L.D. Institute of Indology, 1983. Līlāvaī of Koūhala, ed. A.N. Upadhye, Bombay: Singhi Jain Series, 31, 1949.

Līlāvatīsāra of Jinaratna, ed. H.C. Bhayani, Ahmedabad: L.D. Institute of Indology, 1983; cf. also Fynes 2005 and 2006.

Saṃkhittataraṃgavaīkahā, ed. H.C. Bhayani, Ahmedabad: L.D. Institute of Indology, 1979. Surasuṃdarī of Dhaneśvara, ed. Rajavijaya, Varanasi: Chandraprabha Press, 1916 (reedition

2002); ed. Sadhvi Shree Mahayashashri, Surat: Omkarasuri Aradhana Bhavan, 2004.

\section{Secondary sources}

Billault, A. (1991): La création romanesque dans la littérature grecque à l'époque coloniale. Paris: Presses Universitaires de France.

Bronner, Yigal / Shulman, David / Tubb, Gary (eds.) (2014): Innovations and Turning Points. Toward a History of kāvya Literature. Oxford: Oxford University Press. 
Caudharī, G.C. (1973): Jaina sāhitya kā bṛhad itihāsa, bhāg 6. Vārāṇasī: Parshvanatha Vidyashrama Shodh Samsthan.

Chartier, P. (1996): Introduction aux grandes theories du Roman. Paris: Dunod.

Chojnacki, Ch. (2008a): Kuvalayamālā: Roman jaina de 779 composé par Uddyotanasūri, Vol. 1: Etude. Marburg: Indica et Tibetica, 50.1.

Chojnacki, Ch. (2008b): Kuvalayamālā: Roman jaina de 779 composé par Uddyotanasūri, Vol. 2: Traduction et Annotations. Marburg: Indica et Tibetica, 50.2.

Chojnacki, Ch. (2015): “The emergence of the Campū genre before the $10^{\text {th }}$ century". In: Sanmati, $80^{\text {th }}$ Birthday, Essays in honour of Prof. Hampa Nagarajaiah. Edited by L. Soni and J. Soni. Bangalore: Sapna Press, 97-117.

Chojnacki, Ch. (2016a): "Preserving and Transmitting the Indian Cultural Heritage: On the Genre of Jain Epitomes in the thirteenth century". In: Jaina Narratives. Edited by P. Flügel. London/New York: Routledge (forthcoming).

Chojnacki, Ch. (2016b): "Summarising or adapting the Great Indian Epic? Jain Mahābhārata's Epitomes from the thirteenth century”. In: Jaina Narratives. Edited by P. Flügel. London/ New York: Routledge (forthcoming).

Filliozat, J. (1994): Dictionnaire des littératures de l'Inde. Paris: Presses Universitaires de France, Quadrige.

Fynes, R.C.C. (ed. and tr.) (2005): The Epitome of Queen Lilavati, vol. 1. by Jinaratna. New York: New York University Press, Clay Sanskrit Library.

Fynes, R.C.C. (ed. and tr.) (2006): The Epitome of Queen Lilavati, vol. 2 by Jinaratna. New York: New York University Press, Clay Sanskrit Library.

Glasenapp, H. von (1929): Literaturen Indiens von ihren Anfängen bis zur Gegenwart. WildparkPotsdam: Akademische Verlagsgesellschaft Athenaion.

Lienhard, S. (1984): A History of Classical Poetry. Wiesbaden: Otto Harrassowitz.

Moore, S. (2010): The Novel. An Alternative History. Beginnings to 1600. New York: Continuum. Mukherjee, M. (2008): “The Beginnings of the Indian Novel”. In: A concise History of Indian Literature in English. Edited by A.K. Mehrotra. Delhi: Permanent Black, 105-116.

Pavel, T.G. (2013): The lives of the novel: A History. Paris: Hachette (French version: Paris: Gallimard, 2003).

Piegay-Gros, N. (2005): Le roman. Paris: GF-Flammarion.

Pollock, S. (2006): The Language of the Gods in the World of Men. Sanskrit, Culture, and Power in Premodern India. Delhi: Permanent Black.

Raimond, M. (2015): Le roman. Paris: Armand Colin (revised edition; first edition 1987).

Renou, L. (1985): L'Inde Classique. Paris: Ecole Française d'Extrême Orient.

Rey, P.-L. (1997): Le roman. Paris: Hachette (first edition 1992).

Schubring, W. (1978): Nāyādhammakahāo. Das sechste Anga des Jaina-Siddhānta. Mainz: Franz Steiner Verlag.

Shulman, D. (2014): “Persons Compounded and Confounded: A Reading of Bāṇa's Kādambar $\vec{p}$. In: Innovations and Turning Points. Toward a History of kāvya Literature. Edited by Yigal Bronner, David Shulman, and Gary Tubb. Oxford: Oxford University Press, 277-307.

Tieken, H. (2014): "Bāṇa's death in the Kādambarī". In: Innovations and Turning Points. Toward a History of kāvya Literature. Edited by Yigal Bronner, David Shulman, and Gary Tubb. Oxford: Oxford University Press, 263-276.

Tubb, G. (2014a): “On the Boldness of Bāṇa”. In: Innovations and Turning Points. Toward a History of kāvya Literature. Edited by Yigal Bronner, David Shulman, and Gary Tubb. Oxford: Oxford University Press, 311-354. 
Tubb, G. (2014b): “Something New in the Air: Abhinanda's Rāmacarita and its Ancestry”. In: Innovations and Turning Points. Toward a History of kāvya Literature. Edited by Yigal Bronner, David Shulman, and Gary Tubb. Oxford: Oxford University Press, 357-394. Upadhye, A.N. (ed.) (1949): Līlāvaī of Koūhala. Bombay: Singhi Jain Series, 45. Upadhye, A.N. (ed.) (1959): Kuvalayamālā of Uddyotana. Bombay: Singhi Jain Series, 46. Upadhye, A.N. (ed.) (1970): Kuvalayamālākathā of Ratnaprabha. Bombay: Bhandarkar Oriental Research Institute.

Valette, B. (2005): Le roman. Initiation aux méthodes et aux techniques modernes d'analyse littéraire. Paris: Armand Colin (first edition 1992).

Velankar, H.D. (1944): Jinaratnakośa. An alphabetical register of Jain works and authors. Poona: Bhandarkar Oriental Research Institute.

Warder, A.K. (1988): Indian Kāvya Literature, Vol. 5. Delhi: Motilal Banarsidass.

Warder, A.K. (1990): Indian Kāvya Literature, Vol. 2. Delhi: Motilal Banarsidass.

Warder, A.K. (1992): Indian Kāvya Literature, Vol. 6. Delhi: Motilal Banarsidass.

Warder, A.K. (1994): Indian Kāvya Literature, Vol. 4. Delhi: Motilal Banarsidass.

Winternitz, M. (1991): A History of Indian Literature. Delhi: Munshiram Manoharlal. (third edition). 